\title{
Building a PLS Pathway Model: A Multivariate Approach Innovative Marketing Strategies Facing the Covid-19 Pandemic-Case Study of the Hotel Santika Pekalongan
}

\author{
Wenti Ayu Sunarjo ${ }^{1}$, Najmudin ${ }^{2}$, Refius Pradipta Setyanto ${ }^{3}$ \\ Doctoral student at Universitas Jenderal Soedirman, Jalan Prof. Dr. HR. Bunyamin No. 708, \\ Purwokerto - Jawa Tengah 53122, Indonesia ${ }^{1}$ \\ Lecturer at Universitas Jenderal Soedirman, Jalan Prof. Dr. HR. Bunyamin No. 708, \\ Purwokerto - Jawa Tengah 53122, Indonesia ${ }^{2}$ \\ Lecturer at Universitas Pekalongan, Jalan Sriwijaya No. 3, \\ Pekalongan - Jawa Tengah 51115, Indonesia ${ }^{3}$ \\ wentyaasagita@gmail.com¹,najmudin_najmudin@yahoo.com² ${ }^{2}$,refisetyanto@gmail.com³

\begin{abstract}
Indonesia has been one of the countries affected by the Covid-19 pandemic since early March 2020, especially in the tourism sector, where hospitality has experienced an average turnover of more than $20 \%$. Focusing on the case in a small city in Indonesia in the Central Java Region, Pekalongan City, a hotel, created an innovative marketing strategy by implementing the concept of "private and hygienic", to attract the Public's interest in implementing safety and health protocols. This strategy is designed to treat people who experience boredom while staying at home can enjoy the innovative products offered by the Hotel Santika Pekalongan without fear and worry. This study builds and tests an integrated model to identify relationships between latent variables using multivariate data analysis techniques: Partial least square (PLS), Structural Equation Modeling (SEM) approach with sample data from 159 questionnaires
\end{abstract} \\ distributed to respondents.
}

Keywords: Marketing Strategies, Innovativeness, Marketing capability, Buying Interest, Covid-19 pandemic.

\section{Introduction}

The tourism industry has enjoyed dynamic and continuous growth in the past two decades and has become one of the fastest-growing sectors in economic development worldwide, By UNWTO region, the Americas and Asia and the Pacific both recorded growth close to $6 \%$ in international tourist arrivals, compared to Europe, the world's most visited region, recorded $5 \%$. Arrivals in the Middle East increased by $2 \%$, while in Africa they declined by $3 \%$, mostly due to weak results in North Africa [1]. The findings also broaden the existing tourism literature, demonstrating the moderate effect of the brand's global objectives, destination status (national vs. International), and national brand attitudes on the relationship [2].

However, the conditions differ when the world is flated with the case of Covid-19 (Corona virus), which records more than 200 countries in the world that are currently struggling against the spread of the Covid-19 virus [3] the plague which started in China in December 2019, and in March 2020 has spread in several countries around the world, including Indonesia. Affected 
by the Covid-19 pandemic since early March 2020, Indonesia's economy and social politic are facing a major threat.

Growth economies globally, it demands that the hospitality industry continue to use their marketing strategy as competitiveness under any circumstances. Industrialized Hospitality that includes; restaurants, accommodation, entertainment, and transportation businesses, facing increasingly intense competition and requiring the measurement difference of their service [4]. As research conducted by [5] rapid ranking as a service provider in various aspects of tourism and the Malaysian hospitality sector not only restricts the process of innovation performance but also management commitments in managing services, a common practice to manage service innovations.

Today's business environment is characterized by a wide range of customer needs and rapidly changing markets by presenting a major challenge for many businesses in operational management [6]. To tackle new management quality challenges, especially when the company seeks to find changes in market requirements quickly [7] and industry relations, has been conducted. Among all the areas of functional organizations, marketing and operations contribute to the creation and addition of value, while the rest only contributes to the products and the services of freight delivery [8]. A few researchers also focus on the integration of marketing functions and operations as a means to achieve company performance [9], [6].

While in the purchase decision is also heavily influenced by the prices of the marketed product. In research [10] shows that the company will use price reductions as a strategic lever in responding to the introduction of new products from competitive. [11] Producers are constantly introducing new products to meet the wishes of consumers. In research [12] there are some sellers in socialmedia indonesia "lazada" who make prices unreasonable than normal prices (reasonable prices), so this issue is of particular concern to companies that increase buyer demand.

Marketing capabilities and operations of an enterprise [13] that it is believed to provide a new way for managers to understand the linkages in their functional capabilities. Furthermore, this research is conducted in the capital region, which means that although the population can be considered representative in nature, there may be a huge difference. In terms of behavioural patterns if the research is replicated in small towns.

Thus, to fill the Gap of research, our research was analyzes on consumers from small cities, and we choose the City of Pekalongan during the Pandemic Covid-19. If the company does not do Innovation strategy then it will have an impact on the company's finances, and especially in the field of tourism, no crowded customers visited when no promotions are done that convince the community to buy the product, because the Indonesian government has "Pembatasan Social Berskala Besar (PSBB)" as contained in the Government regulation number 21 year 2020, in order to accelerate handling Corona Virus Disease 2019 (Covid-19).

Hotel Santika Pekalongan creates an innovative marketing strategy that was promoted on social media (Facebook and Instagram) by applying the concept of "private and hygienic", to attract public interest in implementing safety and health protocols. This strategy is designed to treat people who experience boredom while staying at home can enjoy innovative products offered by the Hotel Santika Pekalongan without fear and worry about exposure to the virus. Hotel Santika Pekalongan believes that the innovation product is rightly promoted when the majority of the Pekalongan community, namely Muslims, are fasting Ramadan and will soon be entering the day of victory, which is Eid al-Fitr. 


\section{Theory and Hypotheses}

\subsection{Innovativeness}

Product innovation according to [14] is a new product or service introduced to the market to meet market needs. The type of innovation that can change the products and services that companies offer in the market [15]. In this case, the product must be renewed to complete its position in the market [16]. Indirectly, each company is expected to have a competitive advantage, one of which is to focus on products. [17] Explained that there are three organizational activities that characterize a high level, namely the ability to increase market opportunities, build marketing capabilities in order to increase market opportunities, and the ability to increase market opportunities quickly. This study develops the following hypothesis, which is consistent with this argument;

Hypotheses 1 : Innovativeness is related to marketing capability

Hypotheses 3 : Innovativeness is related to the perceived quality of the destination

Hypotheses 7 : Innovativeness is indirectly related to the perceived quality of destination through marketing capability

Hypotheses 9 : Innovativeness is indirectly related to buying interest through the perceived quality of the destination

Hypotheses 12: Innovativeness is indirectly related to buying interest through marketing capability and the perceived quality of the destination.

\subsection{Proactiveness}

Proactivity is an important driver of firm performance and for the creation of customer value on business-to-business markets. It is however not entirely clear what it is proactive firms actually do to achieve success. Strategies that are proactively competition-oriented take a more dynamic view of the market and strive to either shape the market environment to firms benefits [18], [19], [20]. There study developed the following hypotheses, which are consistent with these arguments;

Hypotheses 2 : Proactiveness is related to marketing capability

Hypotheses 4 : Proactiveness is related to the perceived quality of the destination

Hypotheses 8 : Proactiveness is indirectly related to the perceived quality of destination through marketing capability

Hypotheses 10: Proactiveness is indirectly related to buying interest through the perceived quality of the destination

Hypotheses 13: Proactiveness is indirectly related to buying interest through marketing capability and the perceived quality of the destination

\subsection{Marketing Capability}

On research conducted by in contributing to the literary aspects of marketing capabilities by expanding the focus of research from the outside-inside perspective to the outside-in. The findings suggest that the relationship between the strengths of the supplier company can be transformed into intra-company marketing capabilities. Previous studies have predominantly focused on the antecedent of internal marketing capabilities, reveals that external interfirm relationships can also contribute to strong marketing capabilities [21] ,[22], [23]. This Study developed the following hypotheses, which are consistent with these arguments; 
Hypotheses 5 : Marketing capability is related to perceived quality of the destination Hypotheses 11: Marketing capability is indirectly related to buying interest through perceived quality of the destination

\subsection{Perceive Quality of Destination}

Destination competitiveness has continuous critical challenged tourism market. In the overall tourism system, the destination itself as a unique product which contains various segments, tourism resources (natural attractions, cultural, historical sites, etc.), infrastructure, accommodation, food services, facilities, activities, and so forth. Tourist involvement is considered an appropriate moderating factor in this study due to the nature of the research questions and objective. The study of issues of their tourist activities and trip [24], [25]. The results of research conducted by [26] show that the key success factors and perceived competitiveness of the destinations are significant and have an influence on behavioural intentions of trips to Langkawi Island. The following some directional hypotheses capture these relationships;

Hypotheses 6: Perceived quality of destination is related to buying interest

\subsection{Buying Interset}

[27] we established a general equation from which a buy-in value can be found in the context of defined contribution pension plans with The main point of the novel approach is represented by the strategy which we propose to guarantee the affordability of the buy-in transaction taking into account the demographic model risk. Differ with the research result [28] The study unveiling a positive relationship between impulsive buying tendency and impulsive buying behaviour, and a negative relationship between impulsive buying tendency and self- control validated the measurement qualities of the impulsive tendency measurement scale. Further, it re-confirmed the belief that impulsive buying tendency is higher in individuals with a relatively lower level of self-control, and that impulsive buying tendency positively affected buying interest.

\section{Research Methodology}

Based on the results of interviews conducted with the Assistant Sales Manager of Hotel Santika Pekalongan "Mr. Nur Rofi" on Thursday, 14 May 2020 at 08:43wib, we found clearly about the product innovation of the Hotel Santika Pekalongan which is the latest innovation and different from other hotels with the concept of "private and hygienic", where consumers can still enjoy the atmosphere of the gathering with the core family in the hotel while enjoy the cuisine of the chef hotel which is definitely delicious. In addition, Hotel Santika Pekalongan also innovates the cuisine products especially the one reserved for the take away with beautiful packaging and attractive for consumers who want to enjoy the cuisine of three -Star Hotel encouraging them to stay at home, and easily order the product "package delivery".

Our research this time was tested using Partial Least Squares (PLS) based structural equation modelling SEM. [29]. The target population for this study is only limited to the people of Pekalongan and surrounding areas who know the existence of the Hotel Santika Pekalongan especially for those who have been its customers. We conducted a survey by distributing several question items. We use these surveys to collect data using the convenience 
of non-probability sampling techniques. A total of 170 questionnaires were distributed and after examining the completeness of the data, we removed the incomplete responses. Obtained $(n=159)$ questionnaire that can be used.

\section{Results and Discussion}

As many $(n=159)$ were study respondents, $53.5 \%$ were male, the rest were female. Regarding age, the highest number of respondents was at the age of $35-43$ years $22.6 \%$. They have different educational backgrounds, the majority are $36.5 \%$ masters. In terms of work positions, the majority of respondents in this study were lecturers $37.7 \%$. In our research, the hypothesis is tested based on structural equation modeling using the Partial Least Squares (PLS) method. Following the procedure suggested by, the validity and goodness of fit of the measurement model are estimated before testing the structural relationships described in the structural [29] model (see table. 1).

Table 1. Validity and Reliability for Constructs

\begin{tabular}{|c|c|c|}
\hline \multicolumn{2}{|l|}{ Items } & Loadings \\
\hline \multicolumn{3}{|c|}{ Innovativeness $(\mathrm{AVE}=\mathbf{0 , 6 8 8}$; composite reliability $=\mathbf{0 . 8 9})$} \\
\hline Innovt-1 & $\begin{array}{l}\text { I run a new product innovation made by the Hotel Santika Pekalongan done } \\
\text { so as to attract consumers in the era of Pandemo Covid-19 }\end{array}$ & 1,089 \\
\hline Innovt-2 & $\begin{array}{l}\text { I receive a new product promotion package offered so that consumers can } \\
\text { choose according to their individual tastes }\end{array}$ & 0,980 \\
\hline Innovt-3 & $\begin{array}{l}\text { I agree to the application of "Hygienic" to the innovation of new products } \\
\text { offered one of the things that can control product quality in the era of the co- } \\
19 \text { pandemic }\end{array}$ & 0,815 \\
\hline Innvt-4 & $\begin{array}{l}\text { I See the new product innovations made by Hotel Santika Pekalongan are in } \\
\text { accordance with, and using health standards in the Garry Pandemic era-19 }\end{array}$ & 0,395 \\
\hline \multicolumn{3}{|c|}{ Proactiveness $(\mathrm{AVE}=0,708 ;$ composite reliability $=0,879)$} \\
\hline Proact-1 & $\begin{array}{l}\text { I assume that Hotel Santika Pekalongan is one of the pioneers in introducing } \\
\text { new services in the Garry Pandemic era-19 }\end{array}$ & 0,716 \\
\hline Proact-2 & $\begin{array}{l}\text { Hotel Santika Pekalongan always promotes and a products through social } \\
\text { media }\end{array}$ & 1,064 \\
\hline Proact-3 & $\begin{array}{l}\text { Hotel Santika Displays information on online media in detail so as to be able } \\
\text { to convince consumers }\end{array}$ & 0,738 \\
\hline \multicolumn{3}{|c|}{ Marketing Capability $(\mathrm{AVE}=-\mathbf{0 , 1 6 4}$; composite reliability $=0,134)$} \\
\hline MrktCap-1 & $\begin{array}{l}\text { The content on online media about new products carried out by Hotel Santika } \\
\text { Pekalongan in the pandemic era } 19 \text { is very interesting }\end{array}$ & 0,783 \\
\hline MrktCap-2 & $\begin{array}{l}\text { Content on online media about product innovations carried out by Hotel } \\
\text { Santika Pekalongan in the co- } 19 \text { pandemic era is very beneficial for consumers } \\
\text { who want to add to fatigue while at home (Work from Home or Study from } \\
\text { Home) }\end{array}$ & 1,178 \\
\hline MrktCap-3 & $\begin{array}{l}\text { New product innovations made by Hotel Santika Pekalongan are very } \\
\text { appropriate in the era of the co- } 19 \text { pandemic because they can meet the needs } \\
\text { of consumers to enjoy comfort outside the home that is safe and comfortable }\end{array}$ & 0,734 \\
\hline MrktCap-4 & $\begin{array}{l}\text { The price offered by the new innovation Hotel Santika Pekalongan is } \\
\text { commensurate with the facilities and food menu provided }\end{array}$ & 0,475 \\
\hline \multicolumn{3}{|c|}{ Perceived Quality of Destination (AVE =-0,055; composite reliability =-0,093) } \\
\hline PQD-1 & $\begin{array}{l}\text { The content presented on the Hotel Santika Pekalongan social media helped } \\
\text { me get information about the products offered }\end{array}$ & 0,479 \\
\hline PQD-2 & $\begin{array}{l}\text { I can imagine how the new products in the Hotel Santika in Pekalongan } \\
\text { could become a tourist destination in the era of the co-pandemic- } 19 .\end{array}$ & 0,874 \\
\hline
\end{tabular}




\begin{tabular}{llc}
\hline PQD-3 & $\begin{array}{l}\text { Great Opportunities for new product innovations made by Hotel Santika } \\
\text { Pekalongan can be a priority tourist destination in the co-pandemic era }\end{array}$ & 0,874 \\
PQD-4 & $\begin{array}{l}\text { I agree with the product innovation offered by Hotel Santika Pekalongan to } \\
\text { be an innovation that is superior to consumers in the era of the co-pandemic- }\end{array}$ & 0,964 \\
& $\begin{array}{l}\text { I am pleased to find attractive destinations that are safe and comfortable at } \\
\text { PQD-5 }\end{array}$ & 0,777 \\
& $\begin{array}{l}\text { I } \text { the Hotel Santika Pekalongan } \\
\text { Buying Interest (AVE }=\mathbf{0 , 1 4 4} \text { Composite reliability =-0,075) }\end{array}$ & 0,893 \\
BI-1 & $\begin{array}{l}\text { After seeing new product innovations offered by the Hotel Santika } \\
\text { Pekalongan, I want to find more information about it }\end{array}$ \\
BI-2 & $\begin{array}{l}\text { I am interested after seeing posts in online media conducted by Hotel Santika } \\
\text { Pekalongan about product innovation }\end{array}$ & 0,709 \\
BI-3 & $\begin{array}{l}\text { Am willing to make a purchase on a new product innovation offered by the } \\
\text { Hotel Santika Pekalongan }\end{array}$ & 1,100 \\
\hline
\end{tabular}

In testing the six hypotheses of direct influence testing, there was one hypothesis that was rejected, namely hypotheses 4 , namely the proactiveness of perceived quality of destination of 0.107 (positive value), but with a $\mathrm{p}$ value of $0.086(>0.05)$. While other direct influences were accepted.

In the two segments PLS test results, three hypotheses were accepted or said to mediate. Hypothesis received, between hypothesis 7: innovativeness indirectly significantly affects the perceived quality of destination through marketing capability of $<0.001<0.05$, hypotheses 9 : innovativeness indirectly significantly influences buying interest through the perceived quality of destination of $<0.001<0.05$, hypotheses 11 : marketing capability indirectly significantly influences buying interest through the perceived quality of destination of $<0.001<0.05$. While the three hypotheses that were rejected or did not mediate.

Next, is a three segments PLS test produced two hypotheses, hypothesis 12: accepted or mediating, where innovativeness indirectly significantly influences buying interest through marketing capability and perceived quality of destination, $<0.001>0.05$, then marketing capability and perceived quality of destination mediate the relationship between innovativeness to buying interest of $<0.001$. Whereas in hypotheses 13 : rejected or not mediated, where proactiveness indirectly does not significantly influence buying interest through marketing capability and perceived quality of destination, amounting to $0.076>0.05$. then marketing capability and perceived quality of destination do not mediate the relationship between proactiveness to buying interest.

\section{Conclusion}

Five of the six hypotheses direct results are accepted (positive and significant) focus between each variable. Part of the findings show that the fifth hypotheses has supported empirical data that shows that this marketing strategy is a marketing strategy and related activity, where proactive has great potential to improve B2B enterprise performance, it is important to understand how companies can be proactive so as to [18] achieve the promised profits from proactive.

Three of the six indirect pathways hypotheses are accepted, where innovation has a significant effect on marketing capability and buying interest, and marketing capability has a significant effect on buying interest through perceived quality of destination. Capacity is defined as: sector capability is represented by a set of information that is manifested by all 
available resources and related activities that can be carried out by these resources, as well as knowledge of how these resources and activities can be used effectively, efficiently and economically [30]. With previous research, the study highlighted that the emotional, epistemic, and social values of the tourists played an important role in influencing destination loyalty [31]. Likewise the three path indirect hypothesis, where one hypothesis is accepted, innovation has a positive and significant effect on buying interest through marketing capability and perceived quality of destination.

In our research, clearly seen that the product innovation done by Hotel Santika Pekalongan has an effect on buying interest either directly or through marketing capability or perceived quality of destination. Especially in the conditions of the pandemic covid-19 that requires each company to think about how to sell its products in order to maintain the company's economy well, then The results of this research are very important as one of the basic in drafting recommendations for the development of the tourism sector innovation strategy, particularly hospitality during the pandemic covid-19 and new normal.

\section{Limitation and Future Research}

In our study, we did not escape the limitations, such as the lack of date in numbers and in conducting interviews with the hotel staff and visitors, because this research was conducted during the period of the pandemic covid-19 took place in Indonesia, and also it was limited to the assistant sales manager; and a number of respondents, that is, only respondents who know the Hotel Santika Pekalongan and for consumers who have bought their products. Finally, the research will become more extensive if researchers carry out more about the innovation strategies of many hotels of the same grade in one city or country so that they can be generalized.

\section{Acknowledgements}

The authors are grateful for the support given by Universitas Jenderal Soedirman; Universitas Pekalongan; and all people from Pekalongan City that helped us in our research.

\section{References}

[1] UNWTO. (2016). Unwto Tourism highlights. Retrieved from World Tourism Organization https://www.e-unwto.org/doi/book/10.18111/9789284418145

[2] Luo, J., Dey, L. B., Yalkin, C., Sivarajah, U., \& Punjaisrie, K. (2018). Millennial Chinese consumers' perceived destination brand value. Journal of Business Research.

[3] https:/www.cnnindonesia.com/internasional/20200413234913-134-493234/negara-negara-yangsudah-capai-puncak-pandemi-virus-corona.

[4] Monica Hu, M. L. (2009). Hospitality teams: Knowledge sharing and service innovation performance.Tourism Management,, 30(1), 41-50.

[5] Hussain, K., Konar, R., \& Ali, F. (15. August 2015). Measuring Service Innovation Performance through Team Culture and Knowledge Sharing Behaviour in Hotel Services: A PLS Approach. 6th International Research Symposium in Service Management, s. 35-43. 
[6] Nath, P., \& Subramanian, N. (2010). The Impact of Marketing Capability, Operations Capability and Diversification Strategy on Performance: A Resource-Based View. Industrial Marketing Management, 39(2), 317-329.

[7] Schroeder, R. G., Linderman, K., \& Zhang, D. (2005). Evolution of quality: First fifty issues of production and operations management. Production and Operations Management, 14(4), 468481.

[8] Porter, M. (1985). Competitive advantage. New York: Free Press.

[9] Hausmana, W. M. (2002). hy should marketing and manufacturing work together? Some exploratory empirical results. Journal of Operations Management, 20, 241-257.

[10] Liu, J., Zhai, X., \& Chen, L. (July 2018). The interaction between product rollover strategy and pricing scheme. International Journal of Production Economics, 201, 116-135.

[11] Agmeka, F., Wathoni, R. N., \& Santoso, A. S. (2019). The Influence of Discount Framing towards Brand Reputation and Actual Behaviour in e-commerce. The Fifth Information Systems International Conference 2019, 161, s. 851-858.

[12] Kamboj, S., Goyal, P., \& Rahman, Z. (2015). A resource-based view on marketing capability, operations capability and financial performance: An empirical examination of mediating role. XVIII Annual International Conference of the Society of Operations Management (SOM-14) (s. 406-415). Elsevier Ltd.

[13] Damanpour, F. (1991). Organizational innovation: A meta-analysis of effects of determinants and moderators. Academy of Management Journal, 34(3), 555-590.

[14] Cooper, J. (1998). A Multidimensional Approach to The Adoption of Innovation. Management Decision, 36(8), 493-502.

[15] Johne, A. (1999). Successful market innovation. European Journal of Innovation Management, 2(1), 6-11.

[16] Mavondo, F., \& Farrel, M. (2003). Cultural orientation: Its relationship with market orientation, innovation, and organizations performance. Management Decision, 41 (3), 241-249.

[17] Brege, H., \& Kindstrom, D. (2020). Exploring proactive market strategies. Industrial Marketing Management, 84, 75-88.

[18] Kindstrom, D., Ottoson, M., \& Carlborg, P. (2018). Untraveling-firm level activities for shaping market. Industrial marketing management, 68, 36-45.

[19] Fleischer, J., Nyhuis, P., Liestmann, V., \& Winkler, H. (2004). Proaktive Anlaufsteuerung von Produktionssystem en entlang der Wertschöpfungskette. Industrie Management, 20(4), 29-32.

[20] Yang, Z., Jiang, Y., \& Xie, E. (2019). Buyer-supplier relational strength and buying firm's marketing capability: An outside-in perspective. Industrial Marketing Management, 82, 27-37.

[21] Akdeniz, M. B., Padron, T. G., \& Calanton, R. J. (2010). An integrated marketing capability benchmarking approach to dealer performance through parametric and nonparametric analyses. Industrial Marketing Management, 39(1), 150-160.

[22] O'cass, A., \& Ngo, V. L. (2011). Winning through innovation and marketing: Lessons from Australia and Vietnam. Industrial Marketing Management, 40(8), 1319-1329.

[23] Saffuan, R. A. (2013). reen Technology Design Approach for Liveable Park of Tasik Biru Kundang, Malaysia. Asian Behavioral Studies, 3(8).

[24] Yang, C., Lin, H., \& CC, H. (2010). nalysis of international tourist arrival in China: The Role of world heritage sites. Tourism Management, 31 (6), 827-837.

[25] Zaliha, Z., Radzi, M. S., Salehuddin, M., \& Zahari, M. (2013). Perceived Destination Competitiveness of Langkawi Island, Malaysia: A preliminary finding. Asia Pacific International Conference on Environment-Behavior Studies (s. 801-810). London: P r o c e d i a - S o c i a 1 a $\mathrm{n}$ $\mathrm{d} B$ e havioral S c i ences.

[26] D'Amato, V., Lorenzo, E. D., Haberman, S., \& Sagoo, P. (2018). De-risking strategy: Longevity spread buy-in. Insurance: Mathematics and Economics, 79, 124-136.

[27] Badgaiyan, A. J., Verma, A., \& Dixit, S. (2016). Impulsive buying tendency: Measuring important relationships with a new perspective and an indigenous scale. IIMB Management Review, 28, 186-199.

[28] Sanchez, G. (2013). PLS Path Modeling with R. Berkeley: Trowchez Editions. 
[29] Anderson, J. \&. (1988). Structural modeling in practice: A review and recommended two-step approach. Psychological Bulletin, 103, 411-423

[30] Guerra-Zubiaga, D. A. (2008). Design of a manufacturing knowledge model. International Journal of Computer Integrated Manufacturing, 21(5), 526-539.

[31] Kim, K. H., \& Park, D. B. (2017). Relationship among perceived values, satisfaction and customer loyality: Community-based ecotourism in korea. Journal of travel and tourism marketing, 34, 171-191. 